\title{
Endogenous Lebanese Plants Treating Diabetes and Related Complications
}

\author{
Raafat K*, Boukhary R, Aboul-Ela M and El-Lakany A \\ Department of Pharmaceutical Sciences, Faculty of Pharmacy, Beirut Arab University, 115020, Beirut, Lebanon
}

\begin{abstract}
Diabetes mellitus and its related complications is becoming a serious threat to public health in all parts of the world. The treatment and control of diabetes mainly depend on the synthetic agents, but the fact is that it has never reported total recovery from diabetes. Natural medicines mainly originated in herbs, the traditional Lebanese medicine performed a good experimental practice and is showing a bright future in the therapy of diabetes mellitus and its complications. Based on a large number of Ethnopharmacological research work, numerous bioactive compounds have been found in Lebanese medicinal plants for diabetes. This work presents three natural medicines with regards to their anti-diabetic active principles and/or pharmacological test results, which are commonly used in the traditional Lebanese medical system and have demonstrated experimental anti-diabetic effectiveness. It is highly significant to pay attention to traditional Lebanese natural medicines for treatment and control of diabetes mellitus and its complications.
\end{abstract}

Keywords: Phytomedicine; Diabetes mellitus; Salvia libanotica fruticosa, Centaurea horrida; Hordeum spontaneum; Antioxidant; Diabetic neuropathy

Abbreviations: DM: Diabetes Mellitus; DMSO: Dimethyl Sulfoxide; NC: No Change; SLF: Salvia Libanotica Fruticosa; CH: Centaurea Horrida; HS: Hordeum Spontaneum IP: Intraperitoneal Injection; ROS: Reactive Oxygen Species; CAT: Catalase

\section{Introduction}

Diabetes mellitus $(\mathrm{DM})$ is a major endocrine disorder. Worldwide projections predict that more than 300 million people will suffer from diabetes by the year 2025 and that its management will be expensive $[1,2]$. Numerous studies have been shown that oxidative stress, mediated mainly by hyperglycemia induced generation of free radicals, contributes to the development and progression of diabetes and its complications [3]. Diabetic neuropathy, which is one of the most frequent long-term complications of diabetes mellitus, is frequently accompanied with inferior quality of life [4]. This complication happens in about one quarter of diabetic patients [5]. Painful diabetic neuropathy is combined with symptoms and signs such as burning, tingling or lancing type of spontaneous pain, allodynia and hyperalgesia [6].

The use of endogenous natural plants with therapeutic properties is as ancient as human civilization and, for a long time, plant products were the main sources of drugs [7]. Many plant species are known in folk medicine of different cultures and are used for their hypoglycemic properties [8]. Salvia, Salvia libanotica fruticosa (Lamiaceae) is an evergreen shrub growing in many areas in the world, especially, in Lebanon. Salvia is used as herbal tea and for food flavoring, as well as in cosmetics, perfumery and the pharmaceutical industries throughout world [9]. Salvia fruticosa M. leaves have a folk reputation in the eastern Mediterranean region as a hypoglycemic agent. Salvia fruticosa M. leaves caused a statistically significant reduction in blood glucose levels in alloxan hyperglycemic rabbits [10]. Salvia libanotica fruticosa roots were not reported before to neither have hypoglycemic activity nor manage diabetic neuropathy.

Centaurea is a large genus (Asteraceae) distributed mainly in the Mediterranean area, southwest Asia, North America, south America and in Iran [11]. Centaurea horrida grows in coastal habitats on rocks and seas and is commonly known in Turkey, in Lebanon and in other Mediterranean regions [12]. Many Centaurea species have been used in folk medicine for many purposes as diuretic, bitter tonic, digestive and emmenagogue [13]. In addition; they were used traditionally to cure various ailments such as diarrhea, hypertension and as antibacterial, antitumor and diabetes agents [14]. It was reported that the constituents of Centaurea aspera causing hypoglycemia in rats and mice appeared to be localized primarily in leaf [15]. Extracts of leaves and flowers of Centaurea corubionensis reduced sugar levels in rats with glucoseinduced hyperglycemia, but had no effect on alloxan diabetic animals [16]. It was not reported before that Centaurea horrida herb and roots neither have hypoglycemic activity nor manage diabetic neuropathy.

Wild barley, Hordeum spontaneum K. (Poaceae), are collected from Mediterranean region [17]. Barely is an important cereal food all over the world. It is abundantly used in Asia, Africa, and is also cultivated in Europe, America and Australia. Barely is used as feed for animals as well as food for human consumption. Certain new applications of barely are under investigation for new value added products. In recent years, the importance of barley grains as a nutraceutical ingredient has increased since their high contents of soluble fibers, especially as a rich source of $\beta$-glucan. The most nutritional benefit of $\beta$-glucan in foods is flattening of postprandial blood glucose and insulin rises [18]. Hordeum spontaneum grains were not previously reported to neither have hypoglycemic activity nor manage diabetic neuropathy.

In the current study, DM was provoked using alloxan. Alloxan is a beta-cytotoxin induces "chemical diabetes" (alloxination) in an experimental animals by harming $\beta$-cells of the pancreas leading to decrease the consumption of glucose by the tissue [19]. It is well established that sulphonylureas, like glibenclamide, produce hypoglycemia by increasing the secretion of insulin from pancreas. Sulphonylureas are active in some mild cases of alloxan-induced diabetes, but they are inactive in intense alloxan diabetes [20]. Glibenclamide was utilized in this study as the hypoglycemic positive control agent.

Accordingly, the aim of the present work involves the study of possible hypoglycemic and diabetic neuropathy management by

*Corresponding author: Karim Raafat, Department of Pharmaceutical Sciences, Faculty of Pharmacy, Beirut Arab University (BAU), 115020 Beirut, Lebanon, Tel: +9611300110; Fax: +9611300110 Ext: 2599; E-mail: karim.raafat@yahoo.com, k.raafat@bau.edu.lb

Received July 25, 2013; Accepted August 12, 2013; Published August 19, 2013

Citation: Raafat K, Boukhary R, Aboul-Ela M, El-Lakany A (2013) Endogenous Lebanese Plants Treating Diabetes and Related Complications. Nat Prod Chem Res 1: 112. doi:10.4172/ 2329-6836.1000112

Copyright: $\odot 2013$ Raafat K, et al. This is an open-access article distributed under the terms of the Creative Commons Attribution License, which permits unrestricted use, distribution, and reproduction in any medium, provided the original author and source are credited. 
endogenous Lebanese plants, namely, Salvia libanotica fruticosa roots, Centaurea horrida herb and roots and Hordeum spontaneum grains.

\section{Materials and Methods}

\section{Plant material}

Dried Salvia libanotica fruticosa roots, Centaurea horrida herb and roots and Hordeum spontaneum grains were purchased commercially from Ibn-Al-Nafess herbalist, Beirut, Lebanon. They were authenticated with a reference sample and a dried specimen was deposited in the Pharmaceutical Sciences Department, Faculty of Pharmacy, and Beirut Arab University (BAU).

\section{Preparation of plant extracts}

The dried plant materials were separately dry ground using TCM grinder (TCM, China). All plant materials fine powders were extracted using $2500 \mathrm{ml}$ of $80 \%$ ethanol and were stirred for $24 \mathrm{hrs}$ in their ethanol liquors. During which the flasks were covered by aluminum foil to prevent the light damage. After $24 \mathrm{hrs}$, the extracts were double filtered through a porcelain funnel using $20-25 \mu \mathrm{M}$ filters. The filtered extracts (except, Centaurea horrida herb and roots) were well dried using Rotavap (Buchi, Germany) at temperature $40^{\circ} \mathrm{C}$ under vacuum [21]. Centaurea horrida herb and root extract was spray dried using Labplant Spray Dryer ${ }^{\mathrm{TM}}$ (Labplant, UK).

\section{Animals}

Before experimentation, Male Swiss-Webster mice weight from 18$22 \mathrm{gm}$ and age between 18 and 24 weeks (Faculty of Pharmacy, Beirut Arab University (BAU), were housed for one week. The environment composed of standard mice cages with a 12-h light/dark cycle. The temperature was $22 \pm 1^{\circ} \mathrm{C}$, animals had an open access to water and standard laboratory pellets ( $20 \%$ proteins, $5 \%$ fats, and $1 \%$ multivitamins $[21,22]$. The mice were kept in those conditions for a 7 -day period of adaptation prior to the start of the experiment. Sixteen hours before the experiments, they were fasted overnight, but permitted free access to water. All animal care and experiments were performed in accordance with animal experiment legislation and with approval of the local ethics commission.

\section{Diabetes induction}

Experimental diabetes was induced by i.p. injection of freshly prepared alloxan (Sigma-Aldrich, Germany) dissolved in sterile cold saline $(0.9 \%)$ every 48 -h for three times at a dose of $180 \mathrm{mg} / \mathrm{kg}$. Fasting glucose levels in the blood samples obtained from the tail of each mouse $72 \mathrm{~h}$ after the last alloxan injection were measured with glucose strips test meter. The mice with blood glucose level more than $200 \mathrm{mg} / \mathrm{dL}$ were considered to be diabetic and were used in the experiments.

\section{Acute effect of plant extracts in alloxan-induced diabetic mice}

The diabetic mice were divided, for each extract, into 5 groups of seven animals each. Group I received only vehicle, sterile cold saline (0.9\%), i.p. and served as control. Group II received glibenclamide as reference drug ( $5 \mathrm{mg} / \mathrm{kg}$, i.p.) dissolved in DMSO. The plant extracts, dissolved in vehicle and was administered one extract at a time, at the doses of 12.5, 25 and $50 \mathrm{mg} / \mathrm{kg}$ (except Centaurea horrida herb and root extract dose was 25,50 and $100 \mathrm{mg} / \mathrm{kg}$ ) i.p. to the animals of group III, IV and V, respectively. Blood samples were collected from the tail just prior to and at 1, 2 and $6 \mathrm{~h}$ after dosing. Blood glucose and body weight were determined.

\section{Subacute effect of the plant extracts in alloxan-induced diabetic mice}

The action of plant extracts were also tested during a longer duration of treatment. The mice were divided into groups containing healthy and diabetic animals. Group I (healthy mice, $\mathrm{n}=7$ ) received only vehicle i.p. for 7 days and served as control [23]. The diabetic mice were divided into five groups (II- VI) of seven animals each. Group II received only vehicle, sterile cold saline (0.9\%), i.p. for 7 days and served as diabetic control. Group III received glibenclamide as reference drug $(5 \mathrm{mg} / \mathrm{kg}$, i.p.) dissolved in DMSO for 7 days (positive control). The plant extracts, dissolved in vehicle, was administered at the doses of 12.5, 25 and $50 \mathrm{mg} / \mathrm{kg}$ (except Centaurea horrida herb and root extract doses were 25,50 and $100 \mathrm{mg} / \mathrm{kg}$ ) i.p. to the animals of group IV, V and VI, respectively. Blood samples were collected from the tail at $1^{\text {st }}, 3^{\text {rd }}, 5^{\text {th }}$, and $8^{\text {th }}$ days after each treatment. Blood glucose and antioxidant enzyme (catalase) levels were measured. The body weights of the animals were also recorded at the same day.

\section{Determination of blood glucose concentration}

Blood glucose concentration was determined in blood by Accuchek Active ${ }^{\mathrm{TM}}$ glucose strips in Accu-chek Active ${ }^{\mathrm{TM}}$ Test Meter (Roche, USA). The glucose levels were expressed as $\mathrm{mg} / \mathrm{dl}$.

\section{Assessment of in vivo antioxidant activity}

Catalase (CAT) activity was determined in serum using the modified method described before in literature [24]. Briefly, the reaction mixture at $30^{\circ} \mathrm{C}$ contains $5 \mu \mathrm{L}$ of serum and $395 \mu \mathrm{L}$ of phosphate buffer, $\mathrm{pH}$ 7.0. At zero time, the reaction is started by the addition of $200 \mu \mathrm{L}$ of 38 $\mathrm{mmol} / \mathrm{L}$ of $\mathrm{H}_{2} \mathrm{O}_{2}$ (in phosphate buffer), and the absorbance at $240 \mathrm{~nm}$ is monitored for $5 \mathrm{~mm}$ in a JASCO spectrophotometer (JASCO, Japan). Serum activity CAT activity was expressed as kU/l.

\section{Hot plate test}

For assessment of management of diabetic neuropathy, hot plate analgesia meter (Ugo Basile, Italy) was used. The animals were located one at a time on a hot plate that is maintained at a temperature of $55 \pm$ $0.1^{\circ} \mathrm{C}$. Response latency either to jump or a hindpaw lick was measured by means of an electronic timer. To prevent tissue damage, a cut-off time of $30 \mathrm{~s}$ was done [25].

\section{Tail flick test}

Tail-flick test was done on Tail-flick apparatus (Hugo Sachs Elektronik, Germany) was also used to assess the management of diabetic neuropathy. Briefly, a beam of light was focused on the dorsal surface of the mouse tail and the time until the tail flicked was recorded. The tail-withdrawal latency, time from onset of the radiant heat to the withdrawal of the tail, was detected with a timer. The light intensity in the apparatus was set such that the baseline tail-withdrawal latencies were ca. $5.6 \mathrm{~s}$ in all mice. A cut-off time of $10 \mathrm{~s}$ was done in order to prevent tissue damage [25].

\section{Statistical analysis}

All values were presented as means \pm S.E.M. Statistical differences between the treatments and the controls were tested by two-way ANOVA using the "OriginPro" statistic computer program. A difference in the mean values of $p<0.05$ or less was regarded to be statistically significant. 
Citation: Raafat K, Boukhary R, Aboul-Ela M, El-Lakany A (2013) Endogenous Lebanese Plants Treating Diabetes and Related Complications. Nat Prod Chem Res 1: 112. doi: 10.4172/ 2329-6836.1000112

Page 3 of 8

\section{Results and Discussions}

\section{Acute effect of the plant extracts in alloxan-induced diabetic mice}

Acute effects of various doses of the different plant extracts in diabetic animals were studied using alloxan-diabetic mice. Glibenclamide prevented the drastic increase of blood glucose $1 \mathrm{~h}$ after the glucose loading and reduced the level 2 and $6 \mathrm{~h}$ after the glucose loading.

Salvia libanotica fruticosa root extract (SLF) at all doses $(12.5,25$ and $50 \mathrm{mg} / \mathrm{kg}$ ) showed a significant effect, with blood glucose levels dropped to $50.3,39.4$ and $48.1 \%$, respectively from that of control after $6 \mathrm{~h}$ of glucose administration (Table 1). It therefore appeared that 12.5 $\mathrm{mg} / \mathrm{kg}$ of the SLF extract is the most effective SLF dose on blood glucose of hyperglycemic mice.

Moreover, Centaurea horrida herb and root spray dried methanolic extract $(\mathrm{CH})$ at all doses $(25,50$ and $100 \mathrm{mg} / \mathrm{kg})$ showed a significant effect, with blood glucose levels dropped to $28.1,31.2$ and $49.0 \%$, respectively from that of control after $6 \mathrm{~h}$ of glucose administration (Table 2). It therefore appeared that $100 \mathrm{mg} / \mathrm{kg}$ of the extract of $\mathrm{CH}$ is the most effective $\mathrm{CH}$ dose on acute blood glucose of hyperglycemic mice.

Furthermore, Hordeum spontaneum grain methanolic extract (HS) at all doses $(12.5,25$ and $50 \mathrm{mg} / \mathrm{kg}$ ) showed a significant effect, with blood glucose levels dropped to $33.3,36.6$ and $41.3 \%$, respectively from that of control after $6 \mathrm{~h}$ of glucose administration (Table 3). It therefore appeared that $50 \mathrm{mg} / \mathrm{kg}$ of the HS extract is the most effective HS dose on blood glucose of hyperglycemic mice.

It could be concluded that $100 \mathrm{mg} / \mathrm{kg}$ of $\mathrm{CH}$ extract is the most effective acute hypoglycemic dose of the endogenous Lebanese medicinal plants under investigation.

\section{Subacute effect of various plant extracts on alloxan-induced diabetic mice}

In order to determine the subacute effects, three doses of each extract were administered throughout 8 days consecutively. The blood glucose level of each animal was monitored on $1^{\text {st }}, 3^{\text {rd }}, 5^{\text {th }}$ and $8^{\text {th }}$ days after the administration of the test samples. As shown in Tables 4-6 the blood glucose levels of diabetic control mice were significantly higher than those of the control mice during the experiment period.

In glucose-hyperglycemic mice, SLF at all doses (12.5, 25 and 50 $\mathrm{mg} / \mathrm{kg}$ ) showed a significant effect, with blood glucose levels dropping to $36.7,34.1$ and $33.6 \%$, respectively from that of diabetic control on the $8^{\text {th }}$ day. The highest reduction in blood glucose with SLF was observed with a dose of $50 \mathrm{mg} / \mathrm{kg}$. It was more potent $7.1,8.4$ and $50.2 \%$ than that of $12.5,25 \mathrm{mg} / \mathrm{kg}$ doses and glibenclamide respectively on the $8^{\text {th }}$ day (Table 4).

Additionally, in glucose-hyperglycemic mice, $\mathrm{CH}$ at all doses $(25$, 50 and $100 \mathrm{mg} / \mathrm{kg}$ ) showed a significant effect, with blood glucose levels

\begin{tabular}{|c|c|c|c|c|c|}
\hline \multirow[t]{2}{*}{ Group } & \multirow[t]{2}{*}{ Dose (mg/kg) } & \multicolumn{4}{|c|}{ Mean blood glucose concentration \pm S.E.M. (mg/dL) } \\
\hline & & $0 \mathrm{hr}$ & $0 \mathrm{hr}$ & $2 \mathrm{hr}$ & $6 \mathrm{hr}$ \\
\hline Diabetic control & - & $201.29 \pm 5.60$ & $210.43 \pm 4.50$ & $213.71 \pm 9.70$ & $209.05 \pm 7.30$ \\
\hline Glibenclamide & 5 & $219.20 \pm 3.70$ & $222.14 \pm 1.80$ & $158.24 \pm 2.10$ & $129.14 \pm 2.40^{* *}$ \\
\hline Salvia libanotica fruticosa & 12.5 & $209.56 \pm 4.40$ & $193.33 \pm 4.20$ & $191.57 \pm 2.50$ & $103.89 \pm 4.20^{*}$ \\
\hline Salvia libanotica fruticosa & 25 & $213.66 \pm 3.80$ & $171.54 \pm 4.20$ & $221.43 \pm 3.70$ & $126.77 \pm 3.40^{*}$ \\
\hline Salvia libanotica fruticosa & 50 & $217.44 \pm 3.20$ & $154.56 \pm 1.80$ & $106.99 \pm 2.90^{*}$ & $108.56 \pm 1.80$ \\
\hline
\end{tabular}

S.E.M. mean standard error

${ }^{*} p<0.05$ significant from the control animals.

${ }^{* *} p<0.01$ significant from the control animals.

Table 1. Acute effect of Salvia libanotica fruticosa roots methanolic extract on blood glucose.

\begin{tabular}{|l|c|c|c|c|c|}
\hline \multicolumn{1}{|c|}{ Group } & Dose (mg/kg) & \multicolumn{3}{c|}{ Mean blood glucose concentration \pm S.E.M. (mg/dL) } \\
\hline & & $\mathbf{0} \mathbf{~ h r}$ & $\mathbf{0} \mathbf{~ h r}$ & $\mathbf{2} \mathbf{~ h r}$ \\
\hline Diabetic control & - & $201.29 \pm 5.60$ & $210.43 \pm 4.50$ & $213.71 \pm 9.70$ \\
\hline Glibenclamide & 5 & $219.20 \pm 3.70$ & $222.14 \pm 1.80$ & $158.24 \pm 2.10$ \\
\hline Centaurea horrida & 25 & $211.65 \pm 3.30$ & $202.22 \pm 3.30$ & $170.77 \pm 3.40$ \\
\hline Centaurea horrida & 50 & $214.44 \pm 2.90$ & $239.87 \pm 3.10$ & 15.30 \\
\hline Centaurea horrida & 100 & $219.33 \pm 3.10$ & $154.56 \pm 1.80$ & $106.99 \pm 2.90$ \\
\hline
\end{tabular}

S.E.M.: mean standard error

${ }^{*} p<0.05$ significant from the control animals.

${ }^{* *} p<0.01$ significant from the control animals.

Table 2. Acute effect of Centaurea horrida herb and root spray dried methanolic extract on blood glucose.

\begin{tabular}{|l|c|c|c|c|c|}
\hline \multicolumn{1}{|c|}{ Group } & Dose $\mathbf{( m g / k g )}$ & \multicolumn{2}{c|}{ Mean blood glucose concentration \pm S.E.M. (mg/dL) } \\
\hline & & $\mathbf{0 ~ h r}$ & $\mathbf{0} \mathbf{~ h r}$ & $\mathbf{2} \mathbf{~ h r}$ \\
\hline Diabetic control & - & $201.29 \pm 5.60$ & $210.43 \pm 4.50$ & $213.71 \pm 9.70$ \\
\hline Glibenclamide & 5 & $219.20 \pm 3.70$ & $222.14 \pm 1.80$ & $158.24 \pm 2.10$ \\
\hline Hordeum spontaneum & 12.5 & $112.13 \pm 1.10$ & $231.79 \pm 1.20$ & $164.35 \pm 1.40$ \\
\hline Hordeum spontaneum & 25 & $109.34 \pm 2.60$ & $202.46 \pm 2.40$ & $27.14 \pm 2.40^{* *}$ \\
\hline Hordeum spontaneum & 50 & $107.04 \pm 2.30$ & $218.67 \pm 1.70$ & $139.43 \pm 3.20^{*}$ \\
\hline
\end{tabular}

S.E.M. mean standard error

${ }^{*} p<0.05$ significant from the control animals.

${ }^{* *} p<0.01$ significant from the control animals.

Table 3. Acute effect of Hordeum spontaneum grains methanolic extract on blood glucose. 
Citation: Raafat K, Boukhary R, Aboul-Ela M, El-Lakany A (2013) Endogenous Lebanese Plants Treating Diabetes and Related Complications. Nat Prod Chem Res 1: 112. doi: 10.4172/ 2329-6836.1000112

Page 4 of 8

dropping to $49.6,37.6$ and $33.8 \%$, respectively from that of diabetic control on the $8^{\text {th }}$ day. The highest reduction in blood glucose with $\mathrm{CH}$ was observed with a dose of $100 \mathrm{mg} / \mathrm{kg}$. It was more potent 24.2 , 31.9 and $63.2 \%$ than that of $25,50 \mathrm{mg} / \mathrm{kg}$ doses and glibenclamide respectively on the $8^{\text {th }}$ day (Table 5 ).

Nevertheless, in glucose-hyperglycemic mice, HS at all doses (12.5, 25 and $50 \mathrm{mg} / \mathrm{kg}$ ) showed a significant effect, with blood glucose levels dropping to $9.6,27.1$ and $35.4 \%$, respectively from that of diabetic control on the $8^{\text {th }}$ day. The highest reduction in blood glucose with HS was observed with a dose of $50 \mathrm{mg} / \mathrm{kg}$. It was more potent 72.9, 23.4 and $48.4 \%$ than that of $12.5,25 \mathrm{mg} / \mathrm{kg}$ doses and glibenclamide respectively on the $8^{\text {th }}$ day (Table 6 ).

It could be concluded that $100 \mathrm{mg} / \mathrm{kg}$ of $\mathrm{CH}$ extract is the most effective subacute hypoglycemic dose of the medicinal plants under investigation.

During the subacute administration, mice treated with various doses of SLF, CH and HS extracts and glibenclamide were also monitored for changes in weight (Tables 7-9). The SLF extract showed 5.2, 7.9 and 19.5\% increase in body weight at all doses, 12.5, 25 and 50 $\mathrm{mg} / \mathrm{kg}$ respectively on the $8^{\text {th }}$ day (Table 7 ). The $\mathrm{CH}$ extract showed 1.3 , 1.6 and $4.5 \%$ increase in body weight at all doses, 25, 50 and $100 \mathrm{mg} /$ $\mathrm{kg}$ respectively on the $8^{\text {th }}$ day (Table 8 ). The HS extract showed $1.5,4.9$ and $7.5 \%$ increase in body weight at all doses, 12.5, 25 and $50 \mathrm{mg} / \mathrm{kg}$ respectively on the $8^{\text {th }}$ day (Table 9 ).

It could be suggested that $100 \mathrm{mg} / \mathrm{kg}$ of SLF extract had the most effective subacute rise in weight on the 8th day of treatment with the medicinal plants under investigation.

In order to evaluate in vivo antioxidant effect of the various extracts,
CAT level in serum of each mouse was monitored on $1^{\text {st }}, 3^{\text {rd }}, 5^{\text {th }}$ and $8^{\text {th }}$ days after the administration of the test samples.

As shown in Table 10, diabetic mice treated at all doses, 12.5, 25 and $50 \mathrm{mg} / \mathrm{kg}$ the SLF extract had a gradual rise in serum CAT activity to reach a significant difference on $5^{\text {th }}(8.0,13.3$ and $20.1 \%$ respectively) and $8^{\text {th }}$ day $(6.3,12.4$ and $22.3 \%$ respectively) as compared with diabetic control mice.

Table 11, show that diabetic mice treated at all doses, 25, 50 and 100 $\mathrm{mg} / \mathrm{kg}$ the $\mathrm{CH}$ extract had a gradual rise in serum CAT activity to reach a significant difference on $5^{\text {th }}(10.5,21.5$ and $21.9 \%$ respectively) and $8^{\text {th }}$ day $(13.7,21.0$ and $24.9 \%$ respectively) as compared with diabetic control mice.

Likewise, diabetic mice, as shown in Table 12, treated at all doses, $12.5,25$ and $50 \mathrm{mg} / \mathrm{kg}$ the HS extract had a gradual rise in serum CAT activity to reach a significant difference on $5^{\text {th }}(6.4,16.5$ and $19.1 \%$ respectively) and 8 th day $(7.0,12.0$ and $16.1 \%$ respectively) as compared with diabetic control mice. Therefore, $100 \mathrm{mg} / \mathrm{kg}$ of $\mathrm{CH}$ extract had the most effective subacute rise in serum CAT activity dose on the $8^{\text {th }}$ day of treatment with the medicinal plants under investigation.

It has been found that $\mathrm{CH} 100 \mathrm{mg} / \mathrm{kg}$ is the most effective doses in all groups. This dose has more significant effect on blood glucose level compared to that of the synthetic drug, glibenclamide, as the acute and subacute antihyperglycemic was more potent and prolonged than those of glibenclamide.

Currently, much attention has been focused on the role of oxidative stress. It has been suggested that oxidative stress may comprise the key and common events in the pathogenesis of different diabetic complications [26].

\begin{tabular}{|c|c|c|c|c|c|}
\hline \multirow[t]{2}{*}{ Group } & \multirow[t]{2}{*}{ Dose (mg/kg) } & \multicolumn{4}{|c|}{ Mean blood glucose concentration \pm S.E.M. $(\mathrm{mg} / \mathrm{dL})$} \\
\hline & & 1st day & 3rd day & 5th day & 8th day \\
\hline Control & - & $106.50 \pm 2.50$ & $108.70 \pm 3.60$ & $107.36 \pm 3.20$ & $116.11 \pm 4.70$ \\
\hline Diabetic control $^{\mathrm{a}}$ & - & $201.29 \pm 5.60^{* * *}$ & $210.43 \pm 4.50^{* * *}$ & $213.71 \pm 9.70^{* * *}$ & $209.05 \pm 7.30^{* * *}$ \\
\hline Glibenclamide $^{\mathrm{b}}$ & 5 & $185.20 \pm 3.70$ & $178.03 \pm 2.90$ & $160.04 \pm 2.40^{* *}$ & $170.87 \pm 3.10$ \\
\hline Salvia libanotica fruticosa ${ }^{\text {b }}$ & 12.5 & $149.34 \pm 3.60$ & $140.55 \pm 3.70$ & $140.88 \pm 3.90$ & $138.77 \pm 3.33^{* *}$ \\
\hline Salvia libanotica fruticosa ${ }^{b}$ & 25 & $143.77 \pm 2.90$ & $139.88 \pm 3.10$ & $144.84 \pm 3.40$ & $137.67 \pm 2.20^{* *}$ \\
\hline Salvia libanotica fruticosa ${ }^{\text {b }}$ & 50 & $162.48 \pm 2.60$ & $168.78 \pm 3.80$ & $134.55 \pm 2.40$ & $132.24 \pm 4.20^{* *}$ \\
\hline
\end{tabular}

S.E. M : mean standard error

${ }^{* *} p<0.01$ significant from the control animals.

${ }^{* * *} p<0.001$ significant from the control animals.

${ }^{\text {a }}$ Compared to vehicle control.

${ }^{\mathrm{b}}$ Compared to diabetic control.

Table 4. Subacute effect of Salvia libanotica fruticosa roots methanolic extract on blood glucose.

\begin{tabular}{|c|c|c|c|c|c|}
\hline \multirow[t]{2}{*}{ Group } & \multirow[t]{2}{*}{ Dose (mg/kg) } & \multicolumn{4}{|c|}{ Mean blood glucose concentration \pm S.E.M. (mg/dL) } \\
\hline & & 1st day & 3rd day & 5th day & 8th day \\
\hline Control & - & $106.50 \pm 2.50$ & $108.70 \pm 3.60$ & $107.36 \pm 3.20$ & $116 \pm 4.70$ \\
\hline Diabetic control $^{\mathrm{a}}$ & - & $201.29 \pm 5.60^{* \star *}$ & $210.43 \pm 4.50^{* * *}$ & $213.71 \pm 9.70^{* \star *}$ & $209.05 \pm 7.30^{\star \star *}$ \\
\hline Glibenclamide $^{b}$ & 5 & $185.20 \pm 3.70$ & $178.03 \pm 2.90$ & $160.04 \pm 2.40^{* *}$ & $170.87 \pm 3.10$ \\
\hline Centaurea horrida ${ }^{\mathrm{b}}$ & 25 & $150.44 \pm 3.40$ & $142.69 \pm 3.50$ & $140.98 \pm 3.60$ & $138.33 \pm 3.60^{*}$ \\
\hline Centaurea horrida ${ }^{\mathrm{b}}$ & 50 & $143.77 \pm 2.90$ & $132.88 \pm 3.10$ & $131.48 \pm 3.60$ & $130.55 \pm 2.40^{*}$ \\
\hline Centaurea horrida ${ }^{\mathrm{b}}$ & 100 & $121.84 \pm 2.40$ & $108.56 \pm 1.80$ & $106.66 \pm 1.90$ & $105.42 \pm 1.60^{*}$ \\
\hline
\end{tabular}

S.E.M.: mean standard error

${ }^{*} p<0.05$ significant from the control animals.

${ }^{* *} p<0.01$ significant from the control animals.

*** $p<0.001$ significant from the control animals.

${ }^{\text {a }}$ Compared to vehicle control.

${ }^{\mathrm{b}}$ Compared to diabetic control.

Table 5. Subacute effect of Centaurea horrida herb and root methanolic extract on blood glucose 
Citation: Raafat K, Boukhary R, Aboul-Ela M, El-Lakany A (2013) Endogenous Lebanese Plants Treating Diabetes and Related Complications. Nat Prod Chem Res 1: 112. doi: 10.4172/ 2329-6836.1000112

Page 5 of 8

\begin{tabular}{|c|c|c|c|c|c|}
\hline \multirow[t]{2}{*}{ Group } & \multirow[t]{2}{*}{ Dose (mg/kg) } & \multicolumn{4}{|c|}{ Mean blood glucose concentration \pm S.E.M. (mg/dL) } \\
\hline & & 1st day & 3rd day & 5th day & 8th day \\
\hline Control & - & $106.50 \pm 2.50$ & $108.70 \pm 3.60$ & $107.36 \pm 3.20$ & $116 \pm 4.70$ \\
\hline Diabetic controla $^{a}$ & - & $201.29 \pm 5.60^{* * *}$ & $210.43 \pm 4.50^{* * *}$ & $213.71 \pm 9.70^{\star * *}$ & $209.05 \pm 7.30^{\star \star *}$ \\
\hline Glibenclamide $^{b}$ & 5 & $185.20 \pm 3.70$ & $178.03 \pm 2.90$ & $160.04 \pm 2.40^{* *}$ & $170.87 \pm 3.10$ \\
\hline Hordeum spontaneum ${ }^{\text {b }}$ & 12.5 & $194.21 \pm 1.30$ & $192.89 \pm 2.70$ & $190.45 \pm 3.90$ & $188.89 \pm 3.40^{*}$ \\
\hline Hordeum spontaneum ${ }^{\text {b }}$ & 25 & $165.34 \pm 2.70$ & $153.88 \pm 2.00$ & $154.77 \pm 2.40$ & $152.33 \pm 2.90^{*}$ \\
\hline Hordeum spontaneum ${ }^{\text {b }}$ & 50 & $147.12 \pm 1.50$ & $140.76 \pm 2.10$ & $137.89 \pm 2.60$ & $135.13 \pm 1.80^{* *}$ \\
\hline
\end{tabular}

S.E.M.: mean standard error

${ }^{*} p<0.05$ significant from the control animals.

${ }_{* *}^{*} p<0.01$ significant from the control animals.

${ }_{* * *} p<0.001$ significant from the control animals.

a Compared to vehicle control.

${ }^{\mathrm{b}}$ Compared to diabetic control.

Table 6. Subacute effect of Hordeum spontaneum methanolic extract on blood glucose.

\begin{tabular}{|c|c|c|c|c|c|}
\hline & & 1st day & 3rd day & 5th day & 8th day \\
\hline Control & - & $24.40 \pm 0.50$ & $24.50 \pm 0.60(0.4 \%)$ & $24.66 \pm 0.97(1.1 \%)$ & $25.12 \pm 0.70(3.0 \%)$ \\
\hline Diabetic control $^{\mathrm{a}}$ & - & $25.18 \pm 0.70$ & $25.60 \pm 0.20(1.7 \%)$ & $26.65 \pm 0.80(5.8 \%)$ & $27.19 \pm 0.50(8.0 \%)$ \\
\hline Glibenclamide $^{b}$ & 5 & $21.40 \pm 0.70$ & $26.67 \pm 1.70(24.6 \%)$ & $27.04 \pm 0.40(26.4 \%)$ & $28.87 \pm 1.10(34.9 \%)^{*}$ \\
\hline Salvia libanotica fruticosa ${ }^{b}$ & 12.5 & $20.00 \pm 2.60$ & $20.50 \pm 2.50(2.4 \%)$ & $20.50 \pm 2.90(2.4 \%)$ & $21.10 \pm 2.50(5.2 \%)^{*}$ \\
\hline Salvia libanotica fruticosa ${ }^{\mathrm{b}}$ & 25 & $22.10 \pm 1.40$ & $23.10 \pm 1.90(4.3 \%)$ & $23.50 \pm 1.50(6.0 \%)$ & $24.00 \pm 1.50(7.9 \%)^{*}$ \\
\hline Salvia libanotica fruticosa ${ }^{\mathrm{b}}$ & 50 & $19.55 \pm 2.80$ & $21.22 \pm 2.10(7.9 \%)$ & $22.18 \pm 2.50(11.9 \%)$ & $24.30 \pm 2.40(19.5 \%)^{*}$ \\
\hline
\end{tabular}

S.E.M.: mean standard error

${ }^{*} p<0.05$ significant from the control animals.

a Compared to vehicle control.

${ }^{b}$ Compared to diabetic control.

Table 7. Subacute effect of Salvia libanotica fruticosa roots methanolic extract on body weights in alloxan-induced diabetic mice.

\begin{tabular}{|c|c|c|c|c|c|}
\hline \multirow[t]{2}{*}{ Group } & \multirow[t]{2}{*}{ Dose (mg/kg) } & \multicolumn{4}{|c|}{ Mean body weight \pm S.E.M. (gm) (\% increase from the initial weight) } \\
\hline & & 1st day & 3rd day & 5th day & 8th day \\
\hline Control & - & $24.40 \pm 0.50$ & $24.50 \pm 0.60(0.4 \%)$ & $24.66 \pm 0.97(1.1 \%)$ & $25.12 \pm 0.70(3.0 \%)$ \\
\hline Diabetic control $^{a}$ & - & $25.18 \pm 0.70$ & $25.60 \pm 0.20(1.7 \%)$ & $26.65 \pm 0.80(5.8 \%)$ & $27.19 \pm 0.50(8.0 \%)$ \\
\hline Glibenclamide $^{\text {b }}$ & 5 & $21.40 \pm 0.70$ & $26.67 \pm 1.70(24.6 \%)$ & $27.04 \pm 0.40(26.4 \%)$ & $28.87 \pm 1.10(34.9 \%)^{*}$ \\
\hline Centaurea horrida ${ }^{\mathrm{b}}$ & 25 & $22.00 \pm 2.80$ & $22.10 \pm 2.90(0.5 \%)$ & $22.00 \pm 3.00\left(\mathrm{NC}^{\mathrm{c}}\right)$ & $22.30 \pm 2.50(1.3 \%)$ \\
\hline Centaurea horrida ${ }^{\mathrm{b}}$ & 50 & $31.10 \pm 1.90$ & $31.00 \pm 1.80\left(\mathrm{NC}^{\mathrm{c}}\right)$ & $31.50 \pm 1.70(1.6 \%)$ & $31.60 \pm 1.50(1.6 \%)$ \\
\hline Centaurea horrida $^{\mathrm{b}}$ & 100 & $30.55 \pm 2.90$ & $31.22 \pm 3.10(2.2 \%)$ & $31.18 \pm 2.50(2.0 \%)$ & $32.00 \pm 2.60(4.5 \%)^{*}$ \\
\hline
\end{tabular}

S.E.M.: mean standard error

${ }^{*} p<0.05$ significant from the control animals.

a Compared to vehicle control.

${ }^{b}$ Compared to diabetic control.

${ }^{\mathrm{N}} \mathrm{NC}$ : No change.

Table 8. Subacute effect of Centaurea horrida herb and root methanolic extract on body weights in alloxan induced diabetic mice.

\begin{tabular}{|c|c|c|c|c|c|}
\hline \multirow[t]{2}{*}{ Group } & \multirow[t]{2}{*}{ Dose (mg/kg) } & \multicolumn{4}{|c|}{ Mean body weight \pm S.E.M. (gm) (\% increase from the initial weight) } \\
\hline & & 1st day & 3rd day & 5th day & 8th day \\
\hline Control & - & $24.40 \pm 0.50$ & $24.50 \pm 0.60(0.4 \%)$ & $24.66 \pm 0.97(1.1 \%)$ & $25.12 \pm 0.70(3.0 \%)$ \\
\hline Diabetic controla $^{\mathrm{a}}$ & - & $25.18 \pm 0.70$ & $25.60 \pm 0.20(1.7 \%)$ & $26.65 \pm 0.80(5.8 \%)$ & $27.19 \pm 0.50(8.0 \%)$ \\
\hline Glibenclamide $^{b}$ & 5 & $21.40 \pm 0.70$ & $26.67 \pm 1.70(24.6 \%)$ & $27.04 \pm 0.40(26.4 \%)$ & $28.87 \pm 1.10(34.9 \%)^{*}$ \\
\hline Hordeum spontaneum ${ }^{\mathrm{b}}$ & 12.5 & $25.87 \pm 0.90$ & $25.12 \pm 0.60(-2.8 \%)$ & $26.13 \pm 0.70(1.0 \%)$ & $26.26 \pm 0.50(1.5 \%)$ \\
\hline Hordeum spontaneum ${ }^{\mathrm{b}}$ & 25 & $24.25 \pm 0.70$ & $24.75 \pm 0.40(2.1 \%)$ & $25.07 \pm 0.20(3.4 \%)$ & $25.43 \pm 0.80(4.9 \%)^{*}$ \\
\hline Hordeum spontaneum ${ }^{\mathrm{b}}$ & 50 & $25.36 \pm 0.70$ & $26.24 \pm 0.50(3.5 \%)$ & $26.85 \pm 0.80(5.9 \%)$ & $27.25 \pm 1.10(7.5 \%)^{*}$ \\
\hline
\end{tabular}

S.E.M.: mean standard error

${ }^{*} p<0.05$ significant from the control animals.

a Compared to vehicle control.

${ }^{b}$ Compared to diabetic control.

Table 9. Subacute effect of Hordeum spontaneum methanolic extract on body weights in alloxan-induced diabetic mice.

SLF, CH and HS extracts showed a significant increase in body weight, as an evidence of alleviating of hyperglycemia, as demonstrated before with pharmacotherapies used in management of DM [27].

In our study, the activity of CAT decreased in diabetic mice as reported earlier $[26,28]$ which could be due to inactivation caused by alloxan-generated ROS. Long-term treatment of DM with all doses, especially with the highest dose of the SLF, CH and HS extracts had reversed the activities of this enzymatic antioxidant, which might be due to lessened oxidative stress as evidenced by the elevation in CAT activity. 
Citation: Raafat K, Boukhary R, Aboul-Ela M, El-Lakany A (2013) Endogenous Lebanese Plants Treating Diabetes and Related Complications. Nat Prod Chem Res 1: 112. doi: 10.4172/ 2329-6836.1000112

Page 6 of 8

The mechanism of the hypoglycemic activity of SLF, CH and HS extracts might be independent from insulin secretion. These extracts might inhibit the endogenous glucose production or by the inhibition of intestinal glucose absorption and might play a role in controlling dietary glucose uptake in the small intestinal track [23].

\section{Plant extracts improved neurological function in the diabetic mouse}

Impairment of peripheral nerve conduction is a key indicator for diabetic patients having peripheral neuropathy $[29,30]$. We then examined the effect of various plant extracts treatment on sensory function by measuring the thermal latency with tail flick and hot plate tests. Treatment of the alloxan treated diabetic mice with SLF markedly improved the thermal latency (Figure 1 and 2).

Diabetic mice exhibited transient hyperalgesic response in thermal tests. On the $8^{\text {th }}$ week after alloxan injection, treatment with all doses of SLF, hot-plate latency markedly improved by $29.3,33.2$ and $36.6 \%$ in all SLF doses, $12.5,25$ and $50 \mathrm{mg} / \mathrm{kg}$ respectively, compared to vehicle treated group (Figure 1).

Nevertheless, on the $8^{\text {th }}$ week after alloxan injection, treatment with all doses of SLF, tail-flick latency markedly improved by 29.9, 34.8 and $61.6 \%$ in all SLF doses, $12.5,25$ and $50 \mathrm{mg} / \mathrm{kg}$ respectively, compared to vehicle treated group (Figure 2).

Treatment of the alloxan treated diabetic mice with $\mathrm{CH}$ markedly improved the thermal latency (Figure 3 and 4).

On the $8^{\text {th }}$ week after alloxan injection, treatment with all doses of $\mathrm{CH}$, hot-plate latency markedly improved by $23.8,30.3$ and $45.8 \%$ in all $\mathrm{CH}$ doses, 25, 50 and $100 \mathrm{mg} / \mathrm{kg}$ respectively, compared to vehicle treated group (Figure 3).

\begin{tabular}{|c|c|c|c|c|c|}
\hline \multirow[t]{2}{*}{ Group } & \multirow[t]{2}{*}{ Dose (mg/kg) } & \multicolumn{4}{|c|}{ Catalase level \pm S.E.M. (kU/l) } \\
\hline & & 1st day & 3rd day & 5th day & 8th day \\
\hline Control & - & $39.50 \pm 1.50$ & $40.10 \pm 1.60$ & $39.36 \pm 1.20$ & $40.12 \pm 1.70$ \\
\hline Diabetic controla $^{a}$ & - & $20.17 \pm 1.60^{\star \star *}$ & $19.43 \pm 1.30^{\star * *}$ & $22.51 \pm 1.90^{\star \star *}$ & $24.05 \pm 1.40^{* * *}$ \\
\hline Glibenclamide $^{b}$ & 5 & $21.10 \pm 1.70$ & $23.5 \pm 1.70$ & $30.04 \pm 1.40$ & $30.87 \pm 1.00^{* *}$ \\
\hline Salvia libanotica fruticosa ${ }^{\mathrm{b}}$ & 12.5 & $20.33 \pm 1.40$ & $23.78 \pm 2.60$ & $24.45 \pm 1.50^{*}$ & $25.66 \pm 1.50^{*}$ \\
\hline Salvia libanotica fruticosa ${ }^{\mathrm{b}}$ & 25 & $19.73 \pm 1.40$ & $24.77 \pm 1.30$ & $25.97 \pm 2.70^{*}$ & $27.44 \pm 2.70^{*}$ \\
\hline Salvia libanotica fruticosa ${ }^{\text {b }}$ & 50 & $20.65 \pm 1.60$ & $26.38 \pm 1.50$ & $28.17 \pm 1.30^{*}$ & $30.95 \pm 1.10^{*}$ \\
\hline
\end{tabular}

S.E.M.: mean standard error

${ }^{*} p<0.05$ significant from the control animals.

${ }^{* *} p<0.01$ significant from the control animals.

*** $p<0.001$ significant from the control animals.

${ }^{\text {a }}$ Compared to vehicle control.

${ }^{b}$ Compared to diabetic control.

Table 10. In vivo assessment of the antioxidant activity of Salvia libanotica fruticosa methanolic extract using catalase levels in serum of alloxan-induced diabetic mice.

\begin{tabular}{|c|c|c|c|c|c|}
\hline \multirow[t]{2}{*}{ Group } & \multirow[t]{2}{*}{ Dose (mg/kg) } & \multicolumn{4}{|c|}{ Catalase level \pm S.E.M. (kU/l) } \\
\hline & & 1st day & 3rd day & 5th day & 8th day \\
\hline Control & - & $39.50 \pm 1.50$ & $40.10 \pm 1.60$ & $39.36 \pm 1.20$ & $40.12 \pm 1.70$ \\
\hline Diabetic controla $^{\mathrm{a}}$ & - & $20.17 \pm 1.60^{* * *}$ & $19.43 \pm 1.30^{* * *}$ & $22.51 \pm 1.90^{* * *}$ & $24.05 \pm 1.40^{* * *}$ \\
\hline Glibenclamide $^{b}$ & 5 & $21.10 \pm 1.70$ & $23.5 \pm 1.70$ & $30.04 \pm 1.40$ & $30.87 \pm 1.00^{* *}$ \\
\hline Centaurea horrida ${ }^{b}$ & 25 & $19.45 \pm 1.80$ & $24.97 \pm 2.50$ & $25.14 \pm 1.80^{*}$ & $27.87 \pm 1.10^{*}$ \\
\hline Centaurea horrida ${ }^{b}$ & 50 & $21.37 \pm 1.70$ & $27.43 \pm 1.90$ & $28.66 \pm 2.40^{*}$ & $30.43 \pm 2.60^{*}$ \\
\hline Centaurea horrida ${ }^{b}$ & 100 & $20.65 \pm 1.50$ & $28.38 \pm 1.50$ & $28.81 \pm 1.80^{*}$ & $32.01 \pm 1.10^{*}$ \\
\hline
\end{tabular}

S.E.M.: mean standard error

${ }^{*} p<0.05$ significant from the control animals.

${ }_{* *} p<0.01$ significant from the control animals.

$* * * p<0.001$ significant from the control animals.

${ }^{\text {a }}$ Compared to vehicle control.

${ }^{\mathrm{b}}$ Compared to diabetic control.

Table 11. In vivo assessment of the antioxidant activity of Centaurea horrida methanolic extract using catalase levels in serum of alloxan-induced diabetic mice.

\begin{tabular}{|c|c|c|c|c|c|}
\hline \multirow[t]{2}{*}{ Group } & \multirow[t]{2}{*}{ Dose (mg/kg) } & \multicolumn{4}{|c|}{ Catalase level \pm S.E.M. (kU/l) } \\
\hline & & 1st day & 3rd day & 5th day & 8th day \\
\hline Control & - & $39.50 \pm 1.50$ & $40.10 \pm 1.60$ & $39.36 \pm 1.20$ & $40.12 \pm 1.70$ \\
\hline Diabetic control $^{\mathrm{a}}$ & - & $20.17 \pm 1.60^{\star \star *}$ & $19.43 \pm 1.30^{* * *}$ & $22.51 \pm 1.90^{* * *}$ & $24.05 \pm 1.40^{* * *}$ \\
\hline Glibenclamide $^{b}$ & 5 & $21.10 \pm 1.70$ & $23.5 \pm 1.70$ & $30.04 \pm 1.40$ & $30.87 \pm 1.00^{* *}$ \\
\hline Hordeum spontaneum ${ }^{\text {b }}$ & 12.5 & $21.33 \pm 1.40$ & $23.89 \pm 2.70$ & $24.04 \pm 1.40^{*}$ & $25.87 \pm 1.10^{*}$ \\
\hline Hordeum spontaneum ${ }^{\mathrm{b}}$ & 25 & $20.73 \pm 1.40$ & $26.34 \pm 1.60$ & $26.97 \pm 2.30^{*}$ & $27.33 \pm 2.80^{*}$ \\
\hline Hordeum spontaneum ${ }^{\mathrm{b}}$ & 50 & $21.55 \pm 1.60$ & $27.10 \pm 1.40$ & $27.81 \pm 1.80^{*}$ & $28.65 \pm 1.30^{*}$ \\
\hline
\end{tabular}

S.E.M.: mean standard error

${ }^{*} p<0.05$ significant from the control animals.

** $p<0.01$ significant from the control animals.

*** $p<0.001$ significant from the control animals

${ }^{a}$ Compared to vehicle control.

${ }^{b}$ Compared to diabetic control.

Table 12. In vivo assessment of the antioxidant activity of Hordeum spontaneum grains methanolic extract using catalase levels in serum of alloxan-induced diabetic mice. 
Citation: Raafat K, Boukhary R, Aboul-Ela M, El-Lakany A (2013) Endogenous Lebanese Plants Treating Diabetes and Related Complications. Nat Prod Chem Res 1: 112. doi: 10.4172/ 2329-6836.1000112

Page 7 of 8

Nevertheless, on the $8^{\text {th }}$ week after alloxan injection, treatment with all doses of $\mathrm{CH}$, tail-flick latency markedly improved by 10.4, 25.9 and $32.8 \%$ in all $\mathrm{CH}$ doses, 25,50 and $100 \mathrm{mg} / \mathrm{kg}$ respectively, compared to vehicle treated group (Figure 2).

Treatment of the alloxan treated diabetic mice with HS somewhat improved the thermal latency (Figure 5 and 6).

On the $8^{\text {th }}$ week after alloxan injection, treatment with all doses of HS, hot-plate latency markedly improved by $9.6,18.7$ and $25.0 \%$ in all HS doses 12.5, 25 and $50 \mathrm{mg} / \mathrm{kg}$ respectively, compared to vehicle treated group (Figure 5).

Furthermore, on the $8^{\text {th }}$ week after alloxan injection, treatment with all doses of HS, tail-flick latency markedly improved by $2.3,17.3$ and $28.3 \%$ in all HS doses, $12.5,25$ and $50 \mathrm{mg} / \mathrm{kg}$ respectively, compared to vehicle treated group (Figure 6).

These data suggest that SLF, CH and HS improve peripheral nerve function in the diabetic mouse. Our work highlight that the

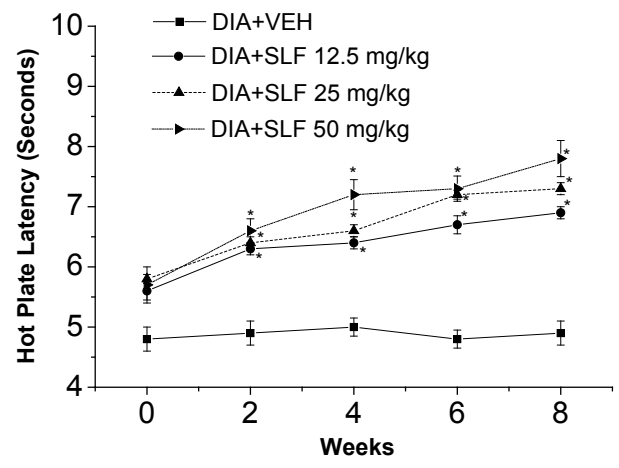

Figure 1: Effect of Salvia Libanotica Fruticosa (SLF) on the hot plate latency in alloxan treated mice. (Closed squares and straight line) DIA+ VEH: diabetic animals treated with vehicle as control. (Open circles and straight line) DIA+ SLF $12.5 \mathrm{mg} / \mathrm{kg}$ : : diabetic animals treated with SLF $12.5 \mathrm{mg} / \mathrm{kg}$. (Up triangles and dashed line) DIA+ SLF $25 \mathrm{mg} / \mathrm{kg}$ : diabetic animals treated with SLF $25 \mathrm{mg} / \mathrm{kg}$. (Right triangles and dashed-dotted line) DIA+ SLF $50 \mathrm{mg} / \mathrm{kg}$ : diabetic animals treated with SLF $50 \mathrm{mg} / \mathrm{kg}$. Data are expressed in mean \pm S.E.M. * $\mathrm{P}<0.05$ is compared with control.

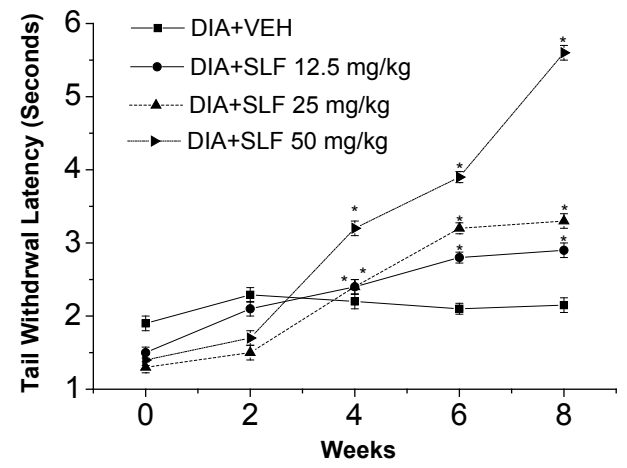

Figure 2: Effect of Salvia Libanotica Fruticosa root extract (SLF) on the tail withdrawal latency in alloxan treated mice. (Closed squares and straight line) $\mathrm{DIA}+\mathrm{VEH}$ : diabetic animals treated with vehicle as control. (Open circles and straight line) DIA+ SLF $12.5 \mathrm{mg} / \mathrm{kg}$ : : diabetic animals treated with SLF $12.5 \mathrm{mg} /$ kg. (Up triangles and dashed line) DIA+ SLF $25 \mathrm{mg} / \mathrm{kg}$ : diabetic animals treated with SLF $25 \mathrm{mg} / \mathrm{kg}$. (Right triangles and dashed-dotted line) DIA+ SLF $50 \mathrm{mg} /$ $\mathrm{kg}$ : diabetic animals treated with SLF $50 \mathrm{mg} / \mathrm{kg}$. Data are expressed in mean \pm S.E.M. ${ }^{*} \mathrm{P}<0.05$ is compared with control.

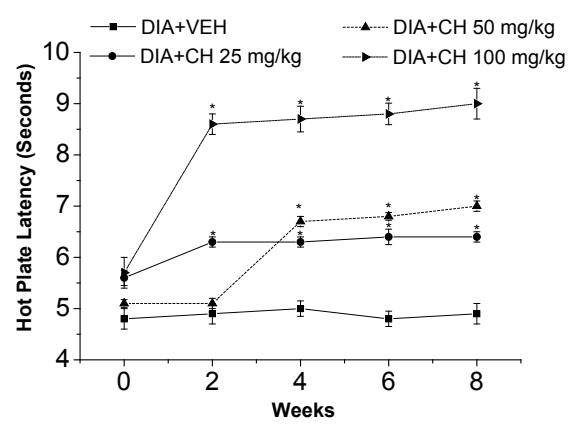

Figure 3: Effect of Centaurea horrida $(\mathrm{CH})$ on the hot plate latency in alloxan treated mice. (Closed squares and straight line) DIA+ VEH: diabetic animals treated with vehicle as control. (Open circles and straight line) DIA $+\mathrm{CH} 25 \mathrm{mg} / \mathrm{kg}$ : diabetic animals treated with $\mathrm{CH} 25 \mathrm{mg} / \mathrm{kg}$. (Up triangles and dashed line) DIA+ $\mathrm{CH} 50 \mathrm{mg} / \mathrm{kg}$ : diabetic animals treated with $\mathrm{CH} 50 \mathrm{mg} / \mathrm{kg}$. (Right triangles and dashed-dotted line) DIA $+\mathrm{CH} 100 \mathrm{mg} / \mathrm{kg}$ : diabetic animals treated with $\mathrm{CH} 100$ $\mathrm{mg} / \mathrm{kg}$. Data are expressed in mean \pm S.E.M. ${ }^{*} \mathrm{P}<0.05$ is compared with control.

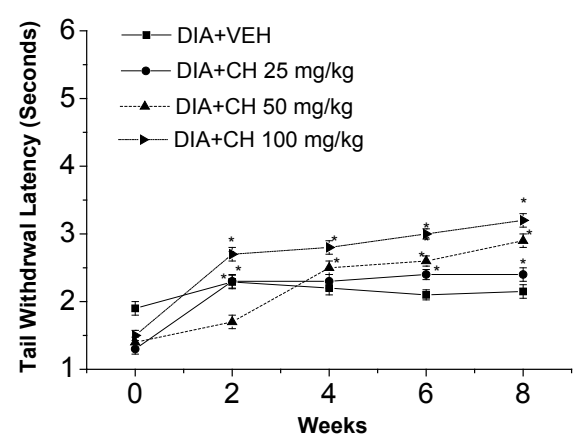

Figure 4: Effect of Centaurea horrida herb and root extract $(\mathrm{CH})$ on the tail withdrawal latency in alloxan treated mice. (Closed squares and straight line) $\mathrm{DIA}+\mathrm{VEH}$ : diabetic animals treated with vehicle as control. (Open circles and straight line) DIA + CH $25 \mathrm{mg} / \mathrm{kg}$ : diabetic animals treated with $\mathrm{CH} 25 \mathrm{mg} / \mathrm{kg}$. (Up triangles and dashed line) $\mathrm{DIA}+\mathrm{CH} 50 \mathrm{mg} / \mathrm{kg}$ : : diabetic animals treated with $\mathrm{CH}$ $50 \mathrm{mg} / \mathrm{kg}$. (Right triangles and dashed-dotted line) $\mathrm{DIA}+\mathrm{CH} 100 \mathrm{mg} / \mathrm{kg}$ : diabetic animals treated with $\mathrm{CH} 100 \mathrm{mg} / \mathrm{kg}$. Data are expressed in mean \pm S.E.M. * $\mathrm{P}<$ 0.05 is compared with control.

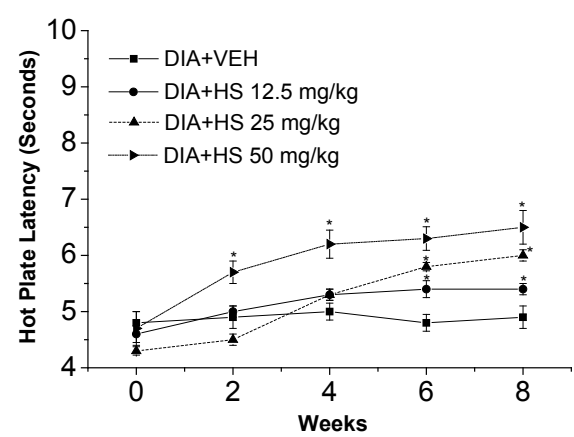

Figure 5: Effect of Hordeum spontaneum grain extract (HS) on the tail withdrawal latency in alloxan treated mice. (Closed squares and straight line) DIA+ VEH: diabetic animals treated with vehicle as control. (Open circles and straight line) $\mathrm{DIA}+\mathrm{HS} 12.5 \mathrm{mg} / \mathrm{kg}$ : diabetic animals treated with HS $12.5 \mathrm{mg} / \mathrm{kg}$. (Up triangles and dashed line) DIA+ HS $25 \mathrm{mg} / \mathrm{kg}$ : diabetic animals treated with HS $25 \mathrm{mg} /$ $\mathrm{kg}$. (Right triangles and dashed-dotted line) DIA+ HS $50 \mathrm{mg} / \mathrm{kg}$ : diabetic animals treated with HS $50 \mathrm{mg} / \mathrm{kg}$. Data are expressed in mean \pm S.E.M. ${ }^{*} \mathrm{P}<0.05$ is compared with control. 
Citation: Raafat K, Boukhary R, Aboul-Ela M, El-Lakany A (2013) Endogenous Lebanese Plants Treating Diabetes and Related Complications. Nat Prod Chem Res 1: 112. doi: 10.4172/ 2329-6836.1000112

Page 8 of 8

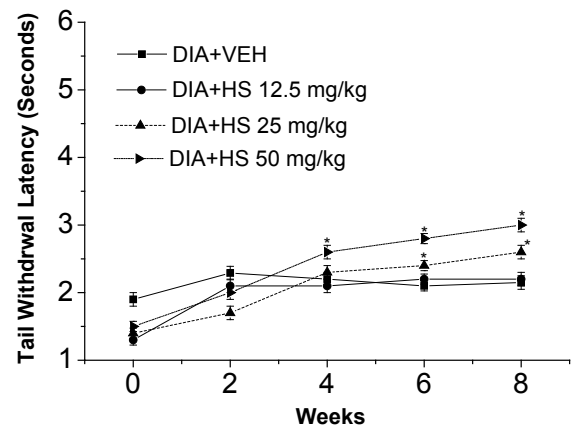

Figure 6: Effect of Hordeum spontaneum grain extract (HS) on the tail withdrawal latency in alloxan treated mice. (Closed squares and straight line) DIA+ VEH: diabetic animals treated with vehicle as control. (Open circles and straight line) $\mathrm{DIA}+\mathrm{HS} 12.5 \mathrm{mg} / \mathrm{kg}$ : diabetic animals treated with HS $12.5 \mathrm{mg} / \mathrm{kg}$. (Up triangles and dashed line) DIA+ HS $25 \mathrm{mg} / \mathrm{kg}$ : diabetic animals treated with HS $25 \mathrm{mg} / \mathrm{kg}$. (Right triangles and dashed-dotted line) DIA+ HS $50 \mathrm{mg} / \mathrm{kg}$ : : diabetic animals treated with HS $50 \mathrm{mg} / \mathrm{kg}$. Data are expressed in mean \pm S.E.M. ${ }^{*} P<0.05$ is compared with control.

improvement of catalase activity might be an indicator for improvement of the peripheral nerve function in the diabetic mouse as well as management of hyperglycemia.

In conclusion, Systemic administration of SLF, CH and HS extracts alleviated hyperalgesia in pain conditions. Our findings provide clinicians promising drugs for the management of the symptoms of diabetic neuropathy.

The present study indicated that endogenous Lebanese plants, explicitly, Salvia libanotica fruticosa roots, Centaurea horrida herb and roots and Hordeum spontaneum grains extracts exerted remarkable hypoglycemic activity and improved peripheral nerve function which will pave the way for management of diabetes and its related complications especially, diabetic neuropathy.

\section{References}

1. King P, Kong MF, Parkin H, MacDonald IA, Barber C, et al. (1998) Intravenous lactate prevents cerebral dysfunction during hypoglycaemia in insulindependent diabetes mellitus. Clin Sci (Lond) 94: 157-163.

2. Somani R, Kasture S, Singhai AK (2006) Antidiabetic potential of Butea monosperma in rats. Fitoterapia 77: 86-90.

3. Rahimi R, Nikfar S, Larijani B, Abdollahi M (2005) A review on the role of antioxidants in the management of diabetes and its complications. Biomed Pharmacother 59: 365-373.

4. Tesfaye S, Selvarajah D (2012) Advances in the epidemiology, pathogenesis and management of diabetic peripheral neuropathy. Diabetes Metab Res Rev 1: 8-14.

5. Quattrini C, Tesfaye S (2003) Understanding the impact of painful diabetic neuropathy. Diabetes Metab Res Rev 1: S2-8.

6. Tesfaye S (2009) Advances in the management of diabetic peripheral neuropathy. Curr Opin Support Palliat Care 3: 136-143.

7. Rates SM (2001) Plants as source of drugs. Toxicon 39: 603-613.

8. Abdel-Barry JA, Abdel-Hassan IA, Al-Hakiem MH (1997) Hypoglycaemic and antihyperglycaemic effects of Trigonella foenum-graecum leaf in normal and alloxan induced diabetic rats. J Ethnopharmacol 58: 149-155.

9. Gali-Muhtasib H, Hilan C, Khater C (2000) Traditional uses of Salvia libanotica
(East Mediterranean sage) and the effects of its essential oils. J Ethnopharmacol 71: 513-520.

10. Perfumi M, Arnold N, Tacconi R (1991) Hypoglycemic activity of Salvia fruticosa Mill. from Cyprus. J Ethnopharmacol 34: 135-140.

11. I Gonzalez Collado, FA Macias, GM Massanet, F Rodriguez Luis (1985) Flavonoids from Centaurea clementei. J Nat Prod 48: 819-822.

12. Flamini G, Bulleri C, Morelli I, Manunta A (2000) A new flavonoid glycoside from Centaurea horrida. J Nat Prod 63: 662-663.

13. Watt JM, Breyer-Brandwijk MG (1962) The medicinal and poisonous plants of southern and eastern Africa. (2ndEdn) Edinburgh: E and S Livingstone LTD 210 .

14. Sarker SD (2012) Bioactivity of Centaurea Presica Bioss (Asteraceae). Arch Biol Sci 64: 517-523.

15. Masso JL, T Adzet (1976) [Hypoglycaemic activity of centaurea aspera L (author's transl)]. Rev Esp Fisiol 32: 313-316.

16. Atta-Ur-Rahman, Zaman K (1989) Medicinal plants with hypoglycemic activity. $\mathrm{J}$ Ethnopharmacol 26: 1-55.

17. Volis S, Mendlinger S, Turuspekov Y, Esnazarov U (2002) Phenotypic and allozyme variation in Mediterranean and desert populations of wild barley, Hordeum spontaneum Koch. Evolution 56: 1403-1415.

18. Asif Ahmad, Faqir Muhammad Anjum, Tahir Zahoor, Haq Nawaz, Ahmad Din (2009) Physicochemical and functional properties of barley $\beta$-glucan as affected by different extraction procedures. International Journal of Food Science and Technology 44: 181-187.

19. Saravanan R, Pari L (2005) Antihyperlipidemic and antiperoxidative effect of Diasulin, a polyherbal formulation in alloxan induced hyperglycemic rats. BMC Complement Altern Med 5: 14.

20. Nammi S, Boini MK, Lodagala SD, Behara RB (2003) The juice of fresh leave of Catharanthus roseus Linn. reduces blood glucose in normal and alloxan diabetic rabbits. BMC Complement Altern Med 3: 4.

21. Karim M Raafat, Hasan Jassar, Maha Aboul-Ela, Abdalla El-Lakany (2013) Protective effects of Origanum majorana L. against Neurodegeneration: Fingerprinting, Isolation and In vivo Glycine Receptors Behavioral Model Inernational Journal of Phytomedicine 5.

22. Raafat K, Breitinger U, Mahran L, Ayoub N, Breitinger HG (2010) Synergistic Inhibition of Glycinergic Transmission In Vitro and In Vivo by Flavonoids and Strychnine. Toxicological Sciences 118: 171-182.

23. Bakirel T, Bakirel U, Keleş OU, Ulgen SG, Yardibi H (2008) In vivo assessment of antidiabetic and antioxidant activities of rosemary (Rosmarinus officinalis) in alloxan-diabetic rabbits. J Ethnopharmacol 116: 64-73.

24. Yasmineh WG, Kaur TP, Blazar BR, Theologides A (1995) Serum catalase as marker of graft-vs-host disease in allogeneic bone marrow transplant recipients: pilot study. Clin Chem 41: 1574-1580.

25. Ulugol A, Oltulu C, Gunduz O, Citak C, Carrara R, et al. (2012) 5-HT7 receptor activation attenuates thermal hyperalgesia in streptozocin-induced diabetic mice. Pharmacol Biochem Behav 102: 344-348.

26. Sepici-Dincel A, Açikgöz S, Cevik C, Sengelen M, Yeşilada E (2007) Effects of in vivo antioxidant enzyme activities of myrtle oil in normoglycaemic and alloxan diabetic rabbits. J Ethnopharmacol 110: 498-503.

27. Russell-Jones D, Khan R (2007) Insulin-associated weight gain in diabetescauses, effects and coping strategies. Diabetes Obes Metab 9: 799-812.

28. Al-Azzawie HF, Alhamdani MS (2006) Hypoglycemic and antioxidant effect of oleuropein in alloxan-diabetic rabbits. Life Sci 78: 1371-1377

29. Said G (2007) Diabetic neuropathy--a review. Nat Clin Pract Neurol 3: 331-340.

30. Tesfaye S, Boulton AJ, Dyck PJ, Freeman R, Horowitz M, et al. (2010) Diabetic neuropathies: update on definitions, diagnostic criteria, estimation of severity, and treatments. Diabetes Care 33: 2285-2293. 